7. Reprod. Fert. (1968) 15, 15-25

\title{
GONADAL AND EPIDIDYMAL SPERM RESERVES IN THE RABBIT: ESTIMATION OF THE DAILY SPERM PRODUCTION
}

\author{
M. C. ORGEBIN-CRIST \\ Vanderbilt University School of Medicine, Department of Obstetrics and Gynecology, \\ Nashville, Tennessee, U.S.A. \\ (Received 3rd October 1966, revised 3rd December 1966)
}

Summary. In the rabbit, daily sperm production by the testes was estimated by determining the total number of spermatozoa and late spermatids contained in a testicular suspension, and the length of the spermatogenic cycle was estimated by an autoradiographic technique. In twenty bucks, 9 to 14 months old (mean weight $3.9 \mathrm{~kg}$ ), which had spent $6.9 \pm 1.8$ weeks in a constant photoperiod of $14 \mathrm{hr}$ light daily, the mean sperm production was $147.4 \times 10^{6}$ /day and $1 \mathrm{~g}$ of their testicular tissue yielded $26.5 \times 10^{6}$ sperm/day. In another group of thirteen bucks, 15 to 16 months old, which had spent $26 \cdot 3 \pm 1 \cdot 7$ weeks under similar lighting conditions, mean sperm production was $115.8 \times 10^{6} /$ day and $1 \mathrm{~g}$ of testis yielded $21.4 \times 10^{6} \mathrm{sperm} /$ day. The difference between the two groups of animals is highly significant and it is postulated that a constant photoperiod is deleterious for sperm production. In rabbits collected from twice a week the daily sperm output was consistently lower than the testicular sperm production, indicating that slightly more than $50 \%$ of the spermatozoa produced are resorbed.

\section{INTRODUCTION}

Daily sperm production has been estimated either by determination of the sperm output at various ejaculation frequencies (Edwards, 1940; Chang, 1945; Ortavant, 1958; Amann \& Almquist, 1961b) or by direct determination on the testes (Amann \& Almquist, 1962b; Kennelly \& Foote, 1964). The first approach may not give a true picture of the sperm production since it does not take into account sperm resorption in the epididymis (in the bull, at least, $57 \%$ of the spermatozoa are resorbed in the epididymis of bulls ejaculated as frequently as eight times weekly (Amann \& Almquist, 1962a). In the present study, the second approach has been chosen, and the daily testicular production has been estimated after determination of the total number of spermatozoa and late spermatids contained in a testicular suspension.

\section{MATERIAL AND METHODS}

\section{Determination of the daily sperm output}

Rabbits used in the present study were bought-in stock; they were kept indoors with $14 \mathrm{hr}$ of light daily, on a Wayne diet M43 and unrestricted water. 
Four New Zealand White and two Dutch-belted male rabbits were used in this study. Semen was collected with an artificial vagina, using a teaser doe, twice a week for a period of 10 weeks. After collection, the tube was separated from the artificial vagina, the gel (when present) was removed and both the gel and the artificial vagina were rinsed. Sperm concentration was determined by haemocytometer counts. At the end of the collection period, animals were killed and testicular sperm reserves determined.

\section{Determination of the gonadal and epididymal sperm reserves}

Two groups of New Zealand White males were used in this study. Animals from group A were 9 to 14 months old, weighed $3.9 \pm 0.5 \mathrm{~kg}$, and had spent $6.9 \pm 1.8$ weeks in artificial light. All rabbits from group B were 15 to 16 months old (except one 2 years old), weighed $3.9 \pm 0.2 \mathrm{~kg}$, and had spent $26 \cdot 3 \pm 1 \cdot 7$ weeks in artificial light before killing.

All the animals were killed by an overdose of Diabutal (Diamond Laboratories), the reproductive system was removed, testis and epididymis were separated and weighed, and the latter was divided into four portions (caput, corpus, cauda and vas deferens). These divisions were made in every case by the same person. The tunica albuginea was carefully removed from the testis and most of the connective tissue was removed from the epididymis. Each component part was cut into very small pieces in $5 \mathrm{ml}$ of $0.9 \% \mathrm{NaCl}$, using curved scissors. After soaking for $1 \mathrm{hr}$ at $4^{\circ} \mathrm{C}$, the macerated tissue was placed in the $50-\mathrm{ml}$ jar of a Serval Omnimixer. It was then homogenized at approximately $7000 \mathrm{rev} / \mathrm{min}$. The homogenate volume was $10 \mathrm{ml}$ except for the corpus epididymidis and the vas deferens $(5 \mathrm{ml})$. The final volume after rinsing the jar was $40 \mathrm{ml}$ for the testis, $20 \mathrm{ml}$ for the caput, $15 \mathrm{ml}$ for the corpus and the vas deferens, and $30 \mathrm{ml}$ for the cauda epididymidis.

The influence on the final sperm count of this technique was determined on the first six rabbits killed. The right and the left testis and each portion of the corresponding epididymis were homogenized, one for $30 \mathrm{sec}$, the other for 2 min, the homogenization time for a given side being alternated from one animal to another. All the suspensions were kept at $4^{\circ} \mathrm{C}$ and an aliquot portion of each was counted after $24,48,72$ and $96 \mathrm{hr}$ of maceration to determine the total number of spermatozoa present in the suspension. Each day, counts were made using a haemocytometer. Two dilutions were prepared from each suspension and two slides were made from each dilution. Before preparing each dilution, the suspension was thoroughly mixed for $3 \mathrm{~min}$ on a Vortex Mixer and before filling each chamber the dilutions were likewise mixed for $1 \mathrm{~min}$.

\section{Duration of spermatogenesis}

Eight New Zealand White male rabbits, averaging $3.3 \mathrm{~kg}$ in body weight, and 8 to 9 months old, were used in this part of the study. Each rabbit was injected with $3 \mathrm{ma}$ of thymidine-methyl- ${ }^{3} \mathrm{H}(6 \cdot 0 \mathrm{c} / \mathrm{mm})$ into the ear vein. Animals were killed $1 \cdot 0,10 \cdot 6,24 \cdot 6,25 \cdot 4,27 \cdot 1,27 \cdot 7,30 \cdot 0,30 \cdot 6$ days after the isotope injection by an overdose of Diabutal. Testes and epididymides were removed immediately. The testis from one side was fixed in Bouin-Holland fluid, then embedded in paraffin wax and sections were prepared. The testis on the other side was 
homogenized with the Serval Omnimixer as described previously. Smears from the testicular suspensions were prepared.

Sections and smears were coated with $\mathrm{NTB}_{2}$ radio-autographic emulsion following the technique described by Kopriwa \& Leblond (1962). After 1 month of exposure at $4^{\circ} \mathrm{G}$ in a $\mathrm{CO}_{2}$ atmosphere, the slides were developed and then stained with Mayer's haemalum solution. All sections and smears were processed at the same time using the same batch of emulsion. For each testis, the percentage of labelled spermatids was determined on 1000 cells counted on five smears by two different observers (500 each). Spermatozoa were viewed under oil immersion and on each slide one longitudinal axis only was traversed, so that no one spermatozoon was included twice. Only cells having more than 3 grains/nucleus were scored as labelled. For each testis, four sections, cut at different levels, were photographed. On each enlarged print, five locations were selected, so as to obtain representative samples for the whole testis. In each location, approximately twenty adjacent tubules were studied; thus the total number of seminiferous tubules examined for each testis was 400 . The classification used for the cycle of the seminiferous epithelium follows the one proposed by Ortavant (1958) in the ram and adopted by Swierstra \& Foote (1963) in the rabbit.

\section{Calculation of testicular sperm production}

The total number of late spermatids and spermatozoa counted in a testicular suspension should represent some function of the daily testicular production. To assess this more precisely, it should be determined from which stages of the seminiferous epithelium cycle the spermatids counted in the testicular suspension come. When these stages are determined, when it is known what percentage of the seminiferous epithelium cycle these stages represent, and when the length of one cycle of the seminiferous epithelium is also known, then the daily testicular production can be calculated from the formula proposed by Amann \& Almquist (1962b).

Daily testicular production $=$

Testis sperm count $\times 100$

Length of one cycle of the seminiferous epithelium $\times$ Percentage of cycle represented

by spermatids counted

\section{RESULTS}

Influence of the technique on the sperm count

Results concerning the influence of the technique on the sperm count are summarized in Table 1 . Increasing the maceration time seems to act unfavourably on the testicular sperm count, but the variance analysis fails to show any significant differences when counts of the testicular or epididymal sperm suspension are made either after $30-\mathrm{sec}$ or 2-min homogenization or when the suspensions are kept at $4^{\circ} \mathrm{C}$ for 24 to $96 \mathrm{hr}$. The sperm counts referred to below are, for the testicular suspension, the count made after $30 \mathrm{sec}$ of homogenization and 24-hr maceration, and for the epididymal suspension, the average of all the counts made. 
TABLE 1

INFLUENGE OF TEGHNIQUE ON THE NUMBER OF SPERM $\left(\times 10^{6}\right)$ REGOVERED FROM A RABBIT TESTIS OR EPIDIDYMIS

\begin{tabular}{|c|c|c|c|c|c|}
\hline \multirow{3}{*}{$\begin{array}{c}\text { Maceration } \\
\text { time }(\text { hr at } \\
\left.4^{\circ} \mathrm{C}\right)\end{array}$} & \multicolumn{4}{|c|}{ Homogenization } & \multirow{3}{*}{$\begin{array}{l}\text { No. of } \\
\text { samples }\end{array}$} \\
\hline & \multicolumn{2}{|c|}{$30 \mathrm{sec}$} & \multicolumn{2}{|c|}{$2 \min$} & \\
\hline & Testis & Epididymis & Testis & Epididymis & \\
\hline $\begin{array}{l}24 \\
48 \\
72 \\
96\end{array}$ & $\begin{array}{l}364 \pm 41 * \\
334 \pm 36 \\
319 \pm 27 \\
319 \pm 37\end{array}$ & $\begin{array}{l}1119 \pm 179 \\
1066 \pm 292 \\
1045 \pm 250 \\
1169 \pm 329\end{array}$ & $\begin{array}{l}352 \pm 44 \\
328 \pm 43 \\
333 \pm 39 \\
323 \pm 33\end{array}$ & $\begin{array}{l}1061 \pm 213 \\
1097 \pm 273 \\
1149 \pm 275 \\
1160 \pm 261\end{array}$ & $\begin{array}{l}6 \\
6 \\
6 \\
6\end{array}$ \\
\hline
\end{tabular}

* Standard error.

TABLE 2

GONADAL AND EXTRA-GONADAL SPERM RESERVES OF RABBITS

\begin{tabular}{|c|c|c|}
\hline & Group $A$ & Group $B$ \\
\hline $\begin{array}{l}\text { No. of animals } \\
\text { Weight of animals (kg) } \\
\text { No. of weeks spent with } 14 \mathrm{hr} \\
\text { light daily } \\
\text { Weight of testis (g) }\end{array}$ & $\begin{array}{l}20 \\
3.9 \pm 0.5^{*} \\
6.9 \pm \\
2 \cdot 78 \pm \quad 0.08\end{array}$ & $\begin{array}{l}13 \\
3.9 \pm 0.2 \\
26 \cdot 3 \pm 1.7 \\
2 \cdot 71 \pm 0.1\end{array}$ \\
\hline $\begin{array}{l}\text { No. spermatozoa/testis }\left(\times 10^{6}\right) \dagger \\
\text { Total No. } \\
\text { Range }\end{array}$ & $\begin{array}{l}401 \pm 25 \\
186 \pm 588\end{array}$ & $\begin{array}{l}315 \pm 23 \\
186 \pm 518\end{array}$ \\
\hline $\begin{array}{l}\text { Weight of epididymis (g) } \\
\text { No. spermatozoa/epididymis } \\
\left(\times 10^{6}\right) \\
\text { Caput } \\
\text { Corpus } \\
\text { Cauda } \\
\text { Vas deferens } \\
\text { Total in tract } \\
\text { Range }\end{array}$ & $\begin{array}{rlr}150 & \pm & 15 \\
58 & \pm & 7 \\
694 & \pm & 72 \\
48 & \pm & 6 \\
950 & \pm & 92 \\
406 & -2283\end{array}$ & $\begin{array}{rlr}125 & \pm & 10 \\
54 & \pm & 7 \\
637 & \pm & 69 \\
55 & \pm & 15 \\
871 & \pm & 101 \\
375 & -1291\end{array}$ \\
\hline
\end{tabular}

* Standard error.

$\uparrow$ For each rabbit the counts from the left and the right side were averaged.

TABLE 3

CORRELATION GOEFFIGIENTS FOR RABBITS FROM GROUPS A AND B

\begin{tabular}{|c|c|c|c|c|c|c|}
\hline & \multicolumn{3}{|c|}{ Gonadal reserve } & \multicolumn{3}{|c|}{ Epididymal reserve } \\
\hline & Group $A$ & Group B & $\begin{array}{c}\text { Groups } \\
A \text { and } B\end{array}$ & Group $A$ & Group $B$ & $\begin{array}{c}\text { Groups } \\
A \text { and } B\end{array}$ \\
\hline \multirow{2}{*}{$\begin{array}{l}\text { Testis weight } \\
\text { Epididymis weight } \\
\text { Body weight } \\
\text { Epididymal reserve }\end{array}$} & 0.33 & $0.85 \dagger$ & $0.61 \dagger$ & \multirow{2}{*}{$\begin{array}{l}0.59 * \\
0.53^{*}\end{array}$} & \multirow{2}{*}{$\begin{array}{l}0.85 \dagger \\
0.44\end{array}$} & \multirow{2}{*}{$\begin{array}{l}0.75 \dagger \\
0.51 \dagger\end{array}$} \\
\hline & $\begin{array}{l}0.24 \\
0.70 \dagger\end{array}$ & $\begin{array}{l}0.29 \\
0.68^{*}\end{array}$ & $\begin{array}{l}0.23 \\
0.64 \dagger\end{array}$ & & & \\
\hline
\end{tabular}

* Significant at the $5 \%$ level of probability.

$\dagger$ Significant at the $1 \%$ level of probability. 
Gonadal and extra-gonadal sperm reserves

Results are summarized in Tables 2 and 3. Gonadal and epididymal sperm reserves are smaller in animals from group $B$ than in those from group $A$. The difference is statistically significant for the gonadal reserves $(P<0.05)$ but not for the epididymal reserves. The deleterious effect on the gonadal reserve of the exposure to a constant photoperiod of $14 \mathrm{hr}$ daily was checked, comparing animals from group A with those of group B. The correlation is negative $(-0.28)$ but not significant. Gonadal reserves are significantly correlated with the testis weight in group B and when both groups are considered together. In group A, data on testis and epididymis weights were available only in some of the animals, and the correlation there is not significant. A rough estimate of the amount of gonadal reserves can be obtained by the following equation based on the thirteen group B rabbits in which testis weight is expressed in grams and gonadal reserve in millions of spermatozoa; gonadal reserve $=(120 \cdot 8)$ (testis weight) $-11 \cdot 5$. There is no correlation between the gonadal reserve and the animal weight. On the contrary, epididymal reserves are significantly correlated with the epididymal weight and to a lesser extent with the body weight. Both gonadal and epididymal reserves are significantly correlated with each other.

The spermatogenic activity of $1 \mathrm{~g}$ of rabbit testis can be calculated by dividing the total number of spermatids and spermatozoa counted in the testicular suspension by the testis weight. In group A animals this index is $144 \cdot 2 \pm$ $8.2 \times 10^{6}$, and in group $B, 116.3 \pm 3.5 \times 10^{6}$. The difference between the two groups is highly significant $(P<0.001)$.

\section{Duration of spermatogenesis}

The relative duration of the eight stages of the seminiferous epithelium cycle determined on 1800 tubules from five different testes is shown in Table 4 .

TABLE 4

RELATIVE FREQUENCY OF THE EIGHT STAGES OF THE SEMINIFEROUS EPITHELIUM CYCLE IN THE RABBIT

\begin{tabular}{c|c}
\hline & $\begin{array}{c}\text { Mean percentage of tubules in each } \\
\text { Stage } \pm S . E .\end{array}$ \\
\cline { 2 - 2 } & $25 \cdot 0 \pm 1 \cdot 9$ \\
2 & $5 \cdot 7 \pm 0 \cdot 6$ \\
3 & $14 \cdot 4 \pm 1 \cdot 4$ \\
4 & $5 \cdot 2 \pm 0 \cdot 6$ \\
5 & $6 \cdot 1 \pm 0.9$ \\
6 & $18 \cdot 4 \pm 1 \cdot 3$ \\
7 & $11.7 \pm 0.9$ \\
8 & $12 \cdot 4 \pm 1.9$ \\
\hline
\end{tabular}

The most advanced labelled germ cell type in specific stages of the seminiferous epithelium cycle was determined for each of the eight injected rabbits. Results are shown in Table 5. The data of Tables 4 and 5 have been combined to determine the number of cycles each interval represents and thus the mean duration of one cycle $(11 \cdot 21 \pm 0 \cdot 08$ days $)$. 
Determination of the stage of the cycle zehere spermatids are released by homogenization

On Day 24, none of the elongated spermatids or spermatozoa in the testicular suspension is labelled (Table 6). In the fixed section of the corresponding testis, no spermatids from stages III to VIII are labelled either. A significant number of labelled spermatids appeared in the testicular suspension on Day $27(3 \cdot 1 \%)$. At that time, of the spermatids from stages III to VIII, $24.8 \%$ are labelled; most of these come from stage III $(77.7 \%)$ and $6.2 \%$ come from stage V. Eighteen hours later, the percentage of labelled spermatids in the testicular suspension has increased to $27.5 \%$, and $32.4 \%$ of the labelled spermatids from stages III to VIII come from stages V and VI. Thus, it would seem that spermatids are released in the testicular suspension from stage $V$ on. It should be noted that the percentages of labelled spermatids coming from stages $\mathrm{V}$ to VIII

TABLE 5

ESTIMATION OF THE DURATION OF ONE GYGLE OF THE SEMINIFEROUS EPITHELIUM

\begin{tabular}{|c|c|c|c|c|}
\hline $\begin{array}{l}\text { Time after } \\
\text { thymidine }{ }^{3} \mathrm{H} \\
\text { injection } \\
\text { (days) }\end{array}$ & $\begin{array}{l}\text { Most advanced } \\
\text { cell type labelled }\end{array}$ & $\begin{array}{l}\text { Cycle and stage } \\
\text { reached by the } \\
\text { most advanced } \\
\text { labelled cell type }\end{array}$ & $\begin{array}{l}\text { No. of cycles } \\
\text { after injection }\end{array}$ & $\begin{array}{l}\text { Duration of } \\
\text { one cycle* } \\
\text { (days) }\end{array}$ \\
\hline 1 & $\begin{array}{l}\text { Primary spermatocyte } \\
\text { (preleptotene) }\end{array}$ & $2-I$ & & \\
\hline $10 \cdot 62$ & $\begin{array}{l}\text { Primary spermatocyte } \\
\text { (pachytene) }\end{array}$ & 3-I & $1 \cdot 00$ & $10 \cdot 6$ \\
\hline $\begin{array}{l}24 \cdot 62 \\
25 \cdot 45 \\
27 \cdot 10 \\
27 \cdot 75 \\
30 \cdot 00 \\
30 \cdot 60\end{array}$ & $\begin{array}{l}\text { Spermatids } \\
\text { Spermatids } \\
\text { Spermatids } \\
\text { Spermatids } \\
\text { Spermatids } \\
\text { Spermatozoa }\end{array}$ & $\begin{array}{l}4-I I I \\
4-I V \\
4-V \\
4-V I \\
4-V I I \\
4-V I I I\end{array}$ & $\begin{array}{l}2 \cdot 20 \\
2 \cdot 25 \\
2 \cdot 31 \\
2 \cdot 50 \\
2 \cdot 62 \\
2 \cdot 74\end{array}$ & $\begin{array}{l}11 \cdot 2 \\
11.3 \\
11.7 \\
11 \cdot 1 \\
11 \cdot 4 \\
11.2\end{array}$ \\
\hline
\end{tabular}

* Mean duration $=11 \cdot 2 \pm 0.08$ days.

$(6 \cdot 2-32 \cdot 4-86 \cdot 1)$ are always higher than the corresponding percentages of labelled spermatids in the testicular suspension $(3 \cdot 1-27 \cdot 5-56 \cdot 0)$. In a crosssection of a seminiferous tubule, it is very commonly found that only a fraction of the spermatids will be labelled. At stage III, it is relatively easy to determine the percentage of labelled versus non-labelled spermatids. At later stages, when elongated spermatids are in tight bundles, the estimation is much more difficult.

\section{Daily testicular production}

Since (1) the length of the cycle is 11.2 days, (2) the percentage of the cycle represented by the spermatids counted is $48 \cdot 6$, and (3) the total sperm count in the testis has been determined, all the data necessary for the calculation of the daily testicular production are available. In group A rabbits, the average sperm production is $73.7 \times 10^{6} /$ testis, i.e. $147.4 \times 10^{6} /$ day/rabbit and $1 \mathrm{~g}$ of testis produces $26.5 \times 10^{6}$ spermatozoa. In group B rabbits, the average sperm production is $57.9 \times 10^{6} /$ testis, i.e. $115.8 \times 10^{6} /$ day/rabbit and $1 \mathrm{~g}$ of testis produces $21.4 \times 10^{6}$ spermatozoa. 


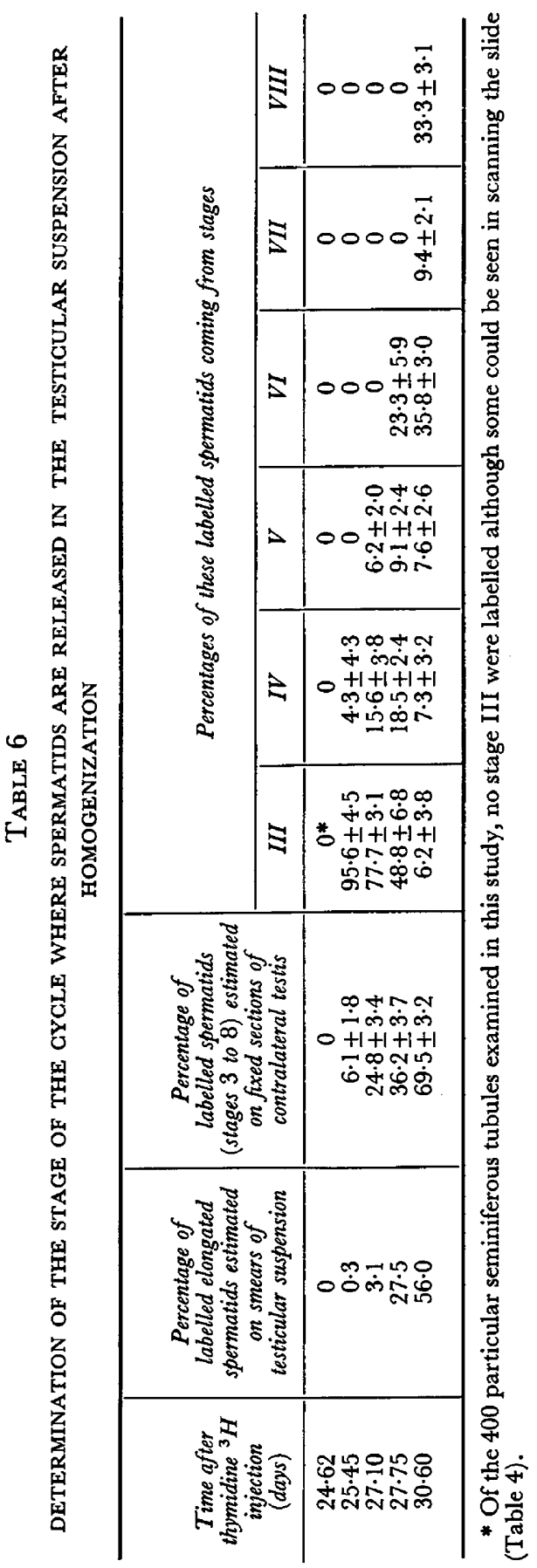


Comparison between daily testicular production and daily sperm output

The results are summarized in Table 7. Daily sperm output is consistently

TABLE 7

PREDICTED DAILY SPERM PRODUCTION COMPARED WITH DAILY SPERM OUTPUT (ONE EJAGULATE TWICE A WEEK)

\begin{tabular}{c|l|c|c|c}
\hline $\begin{array}{c}\text { Rabbit } \\
\text { No. }\end{array}$ & Breed & $\begin{array}{c}\text { Daily sperm } \\
\text { production } \\
\times 10^{6}\end{array}$ & $\begin{array}{c}\text { Daily sperm } \\
\text { output } \\
\times 10^{6}\end{array}$ & $\begin{array}{c}\text { Sperm losses } \\
(\%)\end{array}$ \\
\hline 5 & New Zealand White & 166 & 95 & $42 \cdot 8$ \\
6 & New Zealand White & 134 & 81 & $39 \cdot 6$ \\
24 & New Zealand White & 93 & 26 & $72 \cdot 1$ \\
22 & New Zealand White & 131 & 61 & $53 \cdot 5$ \\
33 & Dutch-belted & 68 & 21 & $69 \cdot 2$ \\
32 & Dutch-belted & 74 & 37 & $50 \cdot 0$ \\
& & & & Mean $=54 \cdot 5$ \\
\hline
\end{tabular}

lower than testicular sperm production at the collection frequency used in this study, the difference averaging $54.5 \%$. They are both highly significantly correlated $(+0.95)$.

\section{DISCUSSION}

Influence of the technique on the sperm count

The efficiency of the technique used for liberation of testicular or epididymal spermatozoa has been discussed by several authors. Ortavant (1958) in the ram and Singh (1962) in the boar found that a maximum number of spermatozoa was obtained after $1 \mathrm{~min}$ homogenization and 48 to $96 \mathrm{hr}$ maceration at $5^{\circ} \mathrm{C}$. Amann \& Almquist (1961a) did not study the effect of the length of the homogenization time, and found a very small difference (although statistically significant) between counts made at the beginning of maceration or after $48 \mathrm{hr}$. In the present study, no statistically significant differences could be found either between 30 -sec or 2-min homogenization or $24,48,72$ or $96 \mathrm{hr}$ maceration.

\section{Daily testicular production}

Different methods are available to determine sperm production directly on the testes. The first group of methods involves a quantitative histological evaluation of the testes. Kennelly \& Foote (1964) estimate the total number of primary spermatocytes by dividing the total volume of primary spermatocyte nuclei/testis by the average volume of these nuclei, and then apply the following formula:

$$
\text { Sperm production }=\frac{\text { Total number of primary spermatocytes } \times 4}{\text { Primary spermatocyte generation interval in days }}
$$

This formula does not take into account the shrinkage due to fixation and embedding of the tissue and, as the authors are well aware, does not take into account the possible degeneration of the spermatocytes and spermatids. To meet the latter criticism, they have recently proposed (Foote, Kennelly \& Swierstra, 1965) a modification of their formula, using the number of round spermatid instead of primary spermatocyte nuclei. The equation proposed by Amann \& Almquist (1962b) is theoretically the most accurate, but involves a 
very long and tedious histological evaluation of the testes and leaves some degree of uncertainty due to the variation in the shrinkage as well as in the thickness of the sections.

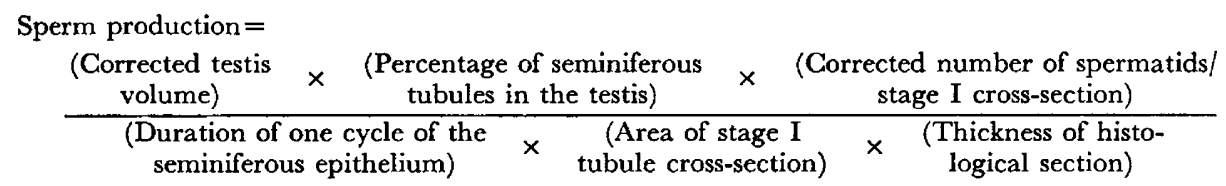

Estimating sperm production from the gonadal reserve is a much simpler method and Amann \& Almquist have compared, in the bull, the theoretical sperm production estimated from the formula above with the one calculated from the gonadal reserve. The value given by the second method was significantly lower than the one given by the first method $\left(9.31 \times 10^{9} / 11.8 \times 10^{9}\right)$, but the authors estimate that errors of measurements being large, one could not conclude which method accurately represented the true daily sperm production.

When using the gonadal reserve technique, each parameter of the formula should be determined with as much accuracy as possible. There are several published values for the length of the seminiferous epithelium cycle in the rabbit: $10.7 \pm 0.5$ days in a mixed breed (Amann, Koefed-Johnsen \& Levi, 1965); 10.9 $\pm 0 \cdot 1$ days for Dutch-belted rabbits (Swierstra \& Foote, 1965); $10 \cdot 3$ days (Orgebin-Crist, 1956). Our estimation of $10 \cdot 3$ days was based on the time required for a daughter spermatozoon from a preleptotene spermatocyte to be released into the seminiferous tubule lumen and for it to arrive in the proximal caput epididymidis. This value should be replaced by the one given in this paper $(11.2 \pm 0.08)$ based on smaller intervals after labelling as preleptotene spermatocyte. The exact stages represented by elongated spermatids and spermatozoa counted in the homogenate are also a critical parameter. Ortavant (1958) estimates that spermatids from stage II to VIII are released, whereas Amann \& Almquist (1962b) assume that only spermatids from stages VI, VII and VIII of the seminiferous epithelium cycle would be counted, but these authors have no definite supporting evidence. It appears that, in the rabbit, and with the liberation and counting techniques described herein, spermatids from stage $\mathrm{V}$ are included as well. The relative frequency of the stages of the seminiferous epithelium cycle has been determined in several species. Our data are in reasonably good agreement with the data published by Swierstra \& Foote (1963) for Dutch-belted rabbits, with the exception of the relative duration of stages II and III. They are very close to the data given by Ortavant (1958) in the ram. Although all three investigations utilized essentially the same classification scheme, slight differences may have existed in the interpretation of both stages, or differences may exist between breeds in the same species. In any case, the relative frequencies for stages V, VI, VII and VIII calculated both from Swierstra \& Foote and from the present study differ only by $8 \%$.

The daily testicular production calculated from our data is $147.4 \times 10^{6}$ for rabbits from group $\mathrm{A}$ and $115.8 \times 10^{6}$ for rabbits from group $\mathrm{B}$. If we choose 10.7 days as the length of the cycle and $40.6 \%$ as the relative frequency of stages V, VI, VII and VIII, then the daily testicular production is even higher (group A, $184.8 \times 10^{6}$ and group B, $145.0 \times 10^{6}$ ). The daily sperm production 
has been estimated previously by the daily sperm output: it averages $58 \times 10^{6}$ with 6 ejaculates/week for 24 weeks (Edwards, 1940), $18 \times 10^{6}$ with 1 ejaculate/ week and $101 \times 10^{6}$ with 1 ejaculate/day for 43 weeks (Gregoire, Bratton \& Foote, 1958), $39 \times 10^{6}$ with 1 ejaculate/week and $88 \times 10^{6}$ with 2 ejaculates $/ 48$ hr for 5 weeks (Desjardins, Kirton \& Hafs, 1965) and $114 \times 10^{6}$ with 2 ejaculates/48 hr for 4 weeks (Amann, 1966). The difference between daily sperm output and daily sperm production appeared to be due primarily to resorption (no losses in urine have been observed in four rabbits left for 2 months in metabolism cages, unpublished observations). In animals collected from daily, these losses have been estimated to represent $58 \%$ of the sperm production in the bull (Amann \& Almquist, 1962a) and 37\% in the boar (Kennelly \& Foote, 1964). In the rabbit with an ejaculation frequency giving the maximal sperm output $(2 \times 48 \mathrm{hr})$, it would appear that losses are less important. But when animals are ejaculated less frequently ( 1 ejaculate twice a week as in the present study), then sperm resorption appears and represents $54 \%$ of the sperm production.

The reason for the difference observed both for daily testicular production and the sperm production/g of testis between rabbits from groups $\mathrm{A}$ and $\mathrm{B}$ is not clear. Rabbits from group B were older than those from group A. They formed a much more homogeneous group, having been born at the same time, brought into the animal quarters at 7 months of age, and kept from that time until slaughter under similar conditions with $14 \mathrm{hr}$ of artificial light daily. The main difference is the amount of time spent in artificial light (6.9/26.3 weeks) and it would seem that in the rabbit a constant photoperiod of $14 \mathrm{hr}$ daily is deleterious for sperm production as it is in the ram (Ortavant, 1958).

\section{ACKNOWLEDGMENTS}

The author is greatly indebted to Dr R. Ortavant for reading and discussing the manuscript, to Miss E. J. Brantley for her technical assistance and to $\mathrm{H}$. Sprague for the statistical analysis of the data. This work was supported in part by NIH Program Project Grant No. HD-00673 and by the National Foundation.

\section{REFERENCES}

Amann, R. P. (1966) Effects of ejaculation frequency and breed on semen characteristics and sperm output of rabbits. F. Reprod. Fert. 11, 291.

Amann, R. P. \& AlmQuist, J. O. (1961a) Reproductive capacity of dairy bulls. I. Technique for direct measurement of gonadal and extra gonadal sperm reserves. F. Dairy Sci. 44, 1.

Amann, R. P. \& AlmQuist, J. O. (1961b) Reproductive capacity of dairy bulls. V. Detection of testicular deficiencies and requirements for experimentally evaluating testis function from semen characteristics. F. Dairy Sci. 44, 2283.

Amann, R. P. \& Almquist, J. O. (1962a) Reproductive capacity of dairy bulls. VI. Effect of unilateral vasectomy and ejaculation frequency on sperm reserves: aspect of epididymal physiology. $\mathcal{J}$. Reprod. Fert. 3, 260.

Amann, R.P. \& Almquist, J. O. (1962b) Reproductive capacity of dairy bulls. VIII. Direct and indirect measurement of testicular sperm production. F. Dairy Sci. 45, 774.

Amann, R. P., Koefed-Johnsen, H. H. \& Levi, H. (1965) Excretion pattern of labelled spermatozoa and the timing of spermatozoa formation and epididymal transit in rabbits injected with thymidine ${ }^{3}$ H. F. Reprod. Fert. 10, 169.

Chang, M. C. (1945) The sperm production of adult rams in relation to frequency of semen collection. 7. agric. Sci. 35,243 .

Desjardins, G., Kirton, K. T. \& Hafs, H. D. (1965) Rabbit sperm output after varying ejaculation frequencies. 7. Anim. Sci. 24, 916. 
Edwards, J. (1940) The effect of unilateral castration on spermatogenesis. Proc. R. Soc. B, 128, 407.

Foote, R. H., KenNelly, J. J. \& Swierstra, E. E. (1965) Predicting maximum daily sperm production by the testis. Cornell Univ. Lab. Proc. 14, 1.

Gregorre, A. T., Bratton, R. W. \& Foote, R. H. (1958) Sperm output and fertility of rabbits ejaculated either once a week or once a day for forty-three weeks. F. Anim. Sci. 17, 243.

Kennelly, J. J. \& Foote, R. H. (1964) Sampling boar testes to study spermatogenesis quantitatively and to predict sperm production. 7. Anim. Sci. 23, 160.

Kopriwa, B. M. \& Leblond, C. P. (1962) Improvements in the coating technique of radioautography. F. Histochem. Cytochem. 10, 269.

Orgebin-CRIST, M. C. (1965) Passage of spermatozoa labelled with thymidine ${ }^{3} \mathrm{H}$ through the ductus epididymidis of the rabbit. F. Reprod. Fert. 10, 241.

Ortavant, R. (1958) Le cycle spermatogénétique chez le Bélier. Thesis, University of Paris, France.

Singh, G. (1962) Réserves spermatiques épididymaires chez le verrat. Ann. Biol. anim. Biochim. Biophys. 2,47 .

Swierstra, E. E. \& Foote, R. H. (1963) Cytology and kinetics of spermatogenesis in the rabbit. $\mathcal{J}$. Reprod. Fert. 5, 309.

SwiERstra, E. E. \& Foote, R. H. (1965) Duration of spermatogenesis and spermatozoan transport in the rabbit based on cytological changes, DNA synthesis and labelling with tritiated thymidine. Am. J. Anat. 116, 401 . 